\title{
Variation and inheritance of ribosomal DNA in Pinus sy/vestris L. (Scots pine)
}

\author{
PÄIVI KARVONEN* \& OUTI SAVOLAINEN \\ Department of Genetics, University of Oulu Linnanmaa, SF-90570 Oulu, Finland
}

\begin{abstract}
Variability in the ribosomal DNA (rDNA) gene family was surveyed in Scots pine (Pinus sylvestris L.) populations from southern and northern Finland. A total of 97 trees were studied with three restriction enzymes, revealing 13 variable rDNA phenotypes. Each rDNA phenotype represents the combined genotype of the eight rDNA loci (NORs, nucleolus organizer regions) that are present in the Scots pine genome. The studied Scots pine populations were equally variable and there was no evidence of geographic differentiation. Of the total rDNA diversity of the species, 86 per cent was found within populations (including within-individual variability) and 14 per cent was found between populations. Within individual trees, one to four rDNA repeat types were distinguished. No variation was found in the coding regions but variable restriction sites were identified in the IGS and transcribed spacer regions. The inheritance pattern of an rDNA variant carrying a $0.4 \mathrm{~kb}$ deletion in the transcribed spacer region was studied. The deletion-carrying rDNA variants were distributed non-randomly across the NOR loci and showed regular Mendelian segregation in the progeny. The observed distribution pattern of rDNA variability suggests that the rate of intrachromosomal homogenization is greater than that of interchromosomal homogenization in Scots pine.
\end{abstract}

Keywords: concerted evolution, digoxigenin-labelling, NOR, P. sylvestris, rDNA, RFLP.

\section{Introduction}

The amount and distribution of variability in multigene families is influenced by several evolutionary forces. In addition to population-level genetic processes (gene flow, selection, genetic drift, etc.), the process of concerted evolution affects variability of the multigene families at the molecular level. Concerted evolution, also known as molecular drive (Dover, 1982), tends to reduce variability between gene copies by molecular, non-Mendelian mechanisms (e.g. gene conversion, unequal crossing-over), resulting in relatively homogeneous gene copies within a species (Arnheim et al., 1980; Dover, 1982; Ohta \& Dover, 1983, 1984). Variability in a multigene family also depends on the number of gene copies, the number of chromosomes on which the gene copies are distributed and the rate of DNA exchange within and between chromosomes (homogenizaton), etc. (Dover, 1982).

Ribosomal DNA (rDNA) is a well characterized multigene family in plants. rDNA occurs as tandemly repeated units at one or several loci with copy numbers

\footnotetext{
*Correspondence.
}

varying from several hundred to thousands of copies per haploid genome (Long \& Dawid, 1980). The basic rDNA repeat consists of a transcription unit and an intergenic spacer (IGS). The transcription unit is composed of genes coding for $18 \mathrm{~S}, 5.8 \mathrm{~S}$ and $26 \mathrm{~S}$ rRNA, separated by two transcribed spacers (ITS1 and ITS2). Molecular genetic surveys of the variability in rDNA have shown that different regions of rDNA repeats show different rates of evolution. Whereas the coding regions of rRNAs are highly conserved even between genetically distant species (Eckenrode et al., 1985), the IGS region is, on the other hand, highly variable among and within plant species. Both restriction-site variation and, more commonly, spacer-length variation occur in the IGS region of plants (Schaal \& Learn, 1988). Spacer-length variation usually results from variable numbers of typically $100-400 \mathrm{bp}$ long subrepeats in the IGS region, as described for Triticum (Appels \& Dvorak, 1982), Hordeum vulgare (SaghaiMaroof et al., 1984), Vicia faba (Yakura et al., 1984), Zea mays (McMullen et al., 1986), Raphanus (Tremousaygue et al., 1988) and a variety of other species. Interspecific comparisons of the transcribed spacers (ITS1 and ITS2) have shown intermediate 
levels of variability but also a short conserved 'corelike' sequence structure (Venkateswarlu \& Nazar, 1991).

The distribution of rDNA variability has been studied in several plant populations (Saghai-Maroof et al., 1984; Learn \& Schaal, 1987; Schaal et al., 1987; King \& Schaal, 1989; Bobola et al., 1992a, Capossela et al., 1992). rDNA variation can be apportioned into several categories: between populations, between individuals within a population and, because of the multiplicity of the rDNA repeats, between rDNA repeat units within an individual. In species with many rDNA-containing loci the analysis of the withinindividual variability can be complex because an individual plant may be heterogeneous with respect to rDNA for several reasons: (1) two or more rDNA variants occur within a single rDNA array, (2) different rDNA variants are associated with different arrays, and (3) heterozygosity (different variants on homologous chromosomes) (Clegg, 1989).

The chromosomal organization and structure of conifer rDNA repeats differ considerably from those of angiosperm species on which a majority of the plant rDNA studies have centred. The size of the rDNA repeats in Pinus radiata (Cullis et al., 1988) and in Pinus sylvestris (Karvonen et al., 1993) is at least 27 $\mathrm{kb}$ and in Picea rubens and Picea mariana it is 32-40 $\mathrm{kb}$ (Bobola et al., 1992b); two- or three-fold as large as typical rDNA repeats of angiosperms. Furthermore, in $P$. radiata (Cullis et al., 1988) and $P$. sylvestris (Karvonen et al., 1993) the rDNA repeats are organized into a minimum of eight to ten nucleolus organizer regions (NOR) whereas non-polyploid angiosperms have generally only one or two NOR loci (Long \& Dawid, 1980; Rogers \& Bendich, 1987).

In this paper we report the results of a survey of rDNA variability in Scots pine (Pinus sylvestris L.). The purpose of this study was firstly, to consider the distribution of rDNA variants between and within individuals and chromosomes in relation to the theory of molecular drive, secondly, to compare rDNA variability of Scots pine to that found in angiosperms, and thirdly, to compare the observed patterns of variability to those found earlier for isozymes is Scots pine. For these purposes, RFLP variability of rDNA repeats was scored for 97 Scots pine individuals and the inheritance pattern of an rDNA repeat variant was studied.

\section{Materials and methods}

\section{Population samples}

Needles for DNA isolation were collected from altogether 97 individual trees from the following loca-

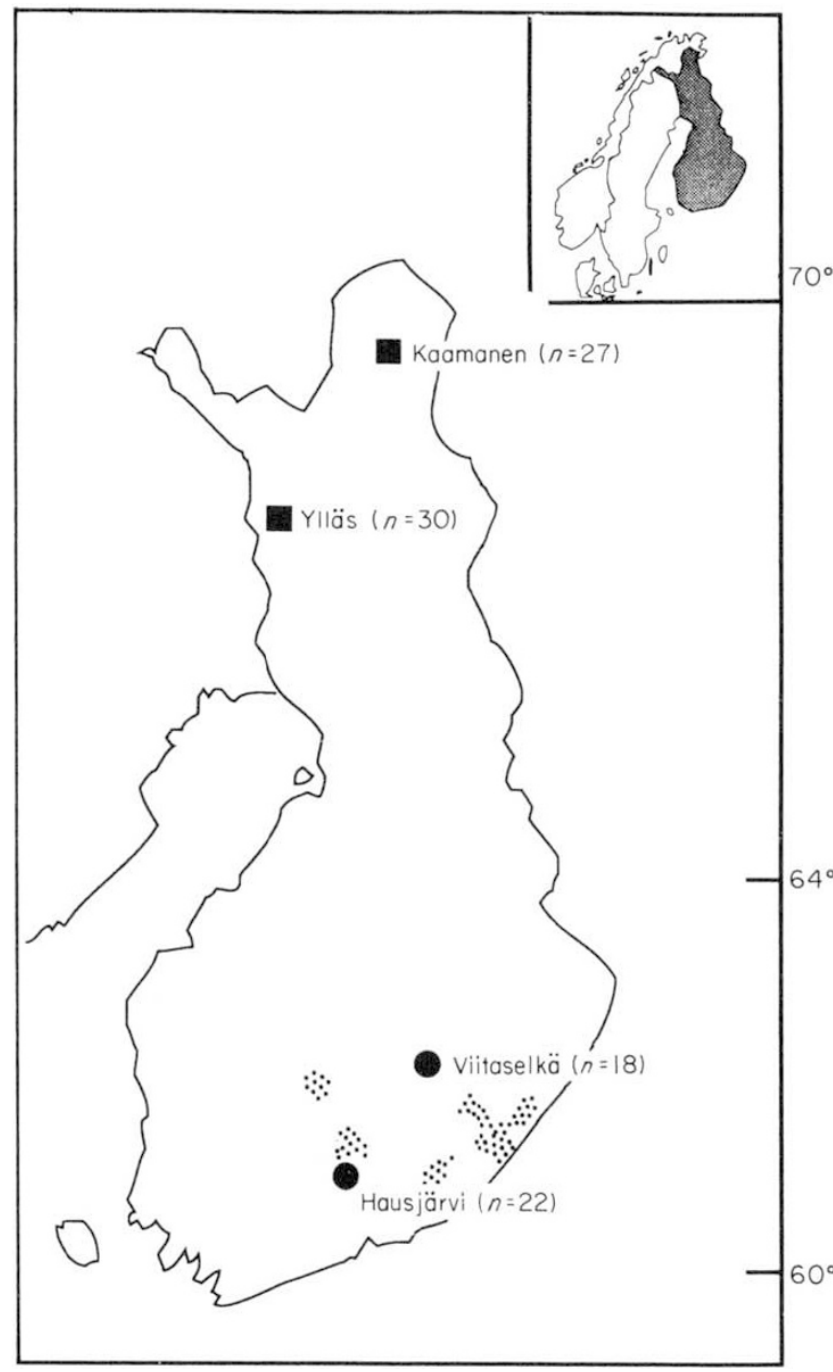

Fig. 1 Map showing geographical origin of the Scots pine DNA samples from northern and southern Finland. Sample sizes in parentheses. The Scots pine individuals in the Hausjärvi and Viitaselkä seed orchards are grafted trees from the regions marked as dotted areas.

tions: Ylläs $(n=30)$ and Kaamanen $(n=27)$ natural populations from northern Finland and the Hausjärvi $(n=22)$ and Viitaselkä $(n=18)$ seed orchards from southern Finland. Locations and sample sizes are shown in Fig. 1. In seed orchards, the trees are phenotypically selected trees collected from a restricted area in southern Finland (dotted area in Fig. 1).

\section{Controlled cross}

$F_{1}$ progeny (31 individuals) of the controlled cross E636C $\times$ E702 from the Hausjärvi seed orchard were used to study the inheritance of rDNA variation. Restriction maps of the rDNA repeat units present in 
the parental trees were constructed by means of a series of single and double digestions, using the previous restriction map of the Scots pine rDNA repeat (Karvonen et al., 1993) as a reference.

\section{DNA isolation and Southern blotting}

DNA was extracted from $10 \mathrm{~g}$ of needles by a modification of the CTAB method (Murray \& Thompson, 1980; Wagner et al., 1987). Needles were frozen with liquid nitrogen and quickly homogenized into crude power. The powder was mixed with cold DNA extraction buffer and further homogenized with a Polytron homogenizer. After these steps the DNA extraction followed the procedure of Wagner et al. (1987). Some of the DNA samples were further purified by cesium chloride ultracentrifugation but this step was later found to be unnecessary.

Then 3-5 $\mu \mathrm{g}$ of DNA from each sample was digested with restriction endonucleases according to the manufacturer's instructions (Boehringer Mannheim). To ensure complete digestions, 8-10 units of enzyme were used per $1 \mu \mathrm{g}$ of DNA for more than 8 h. Restriction fragments were separated by electrophoresis in 0.3-0.7 per cent agarose gels. The gels were depurinated in $0.25 \mathrm{M} \mathrm{HCl}$ for $15-20 \mathrm{~min}$, denatured in $0.5 \mathrm{M} \mathrm{NaOH} ; 1.5 \mathrm{M} \mathrm{NaCl}$ for $2 \times 20 \mathrm{~min}$ and neutralized in $3 \mathrm{M} \mathrm{NaCl}$; $0.5 \mathrm{M}$ Tris- $\mathrm{HCl}, \mathrm{pH} 7.5$ for $2 \times 20$ min. DNA was transferred from gels to Hybond $\mathrm{N}^{+}$ nylon membrane (Amersham) by vacuum blotting, according to the manufacturer's instructions (VacuGene XL, Pharmacia). After blotting the membrane was shortly washed in $2 \times \mathrm{SSC}$, dried completely and U.V.-crosslinked for $2 \mathrm{~min}(365 \mathrm{~nm})$.

\section{Hybridization and detection}

The membrane was hybridized with a pBG35 plasmid that contains the complete rDNA repeat unit from flax (Goldsbrough \& Cullis, 1981). The pBG35 DNA or purified insert-DNA $(1-2 \mu \mathrm{g})$ was labelled by random primed incorporation of digoxigenin-dUTPs for $20 \mathrm{~h}$. The labelling, hybridization and detection of the hybridized membranes were performed according to the detailed instructions supplied with the digoxigeninkit (Boehringer Mannheim), with the following modifications.

Prehybridization ( $2 \mathrm{~h}$ ) and hybridization (overnight) were performed at $65^{\circ} \mathrm{C}$ in the Hybaid Mini hybridization oven. Membranes were washed $2 \times 5 \mathrm{~min}$ in $2 \times$ SSC; 0.1 per cent SDS at room temperature and $2 \times 15 \mathrm{~min}$ in $0.5 \times \mathrm{SSC}$; 0.1 per cent SDS at $65^{\circ} \mathrm{C}$. The detection, which is based on an enzyme-linked antibody reaction, was done according to the manufac- turer's instructions. The colour reaction was terminated after 18-20 h.

\section{Results}

\section{Variable rDNA hybridization patterns}

In a preliminary survey, the ability of 11 restriction enzymes to detect rDNA variation was tested, using the 22 Scots pine individuals from the Hausjärvi seed orchard as a test population. From the 11 tested enzymes (BamHI, BclI, CfoI, DraI, EcoRI, EcoRV, HindIII, KpnI, SacI, Sau3A, XbaI) three restriction enzymes proved to be useful in detecting rDNA variability. BamHI, EcoRI and SacI produced variable, easily scorable hybridization patterns with rDNA fragments within a suitable size range. DraI, which cuts once within the Scots pine rDNA repeat, produced a single, $27 \mathrm{~kb}$ rDNA fragment in all trees from Hausjärvi, indicating that all repeats were of about the same size (data not shown). However, slight size differences between rDNA repeat lengths may have been undetectable owing to the limited separation of longer than $20 \mathrm{~kb}$ DNA fragments in electrophoresis.

Examples of the variable rDNA hybridization patterns produced with EcoRI and $S a c$ I are presented in Fig. 2. Both of these enzymes produced consistently large, over $20 \mathrm{~kb}$ rDNA fragments, which were persistently observed even in DNA samples purified by $\mathrm{CsCl}$-ultracentrifugation and digested with excessive amount of enzyme and/or long incubation. Therefore it was assumed that these rDNA fragments are due to restriction sites blocked by DNA methylation, which have been commonly observed in plant rDNA, especially in inactive genes (Watson et al., 1987; Flavell \& O’Dell, 1990).

The variable rDNA fragments in Fig. 2 showed hybridization signals of lower intensity than the invariable rDNA fragments, indicating either low homology with the pBG35 probe or low concentration of the particular rDNA fragment among the rDNA repeats (intraindividual heterogeneity). The variable rDNA fragments cut with $\mathrm{SacI}$ in Fig. $2 \mathrm{~b}$ were 7.1-9.1 $\mathrm{kb}$ long and contained areas spanning the $3^{\prime}$ end of the $25 \mathrm{~S}$ gene and the $5^{\prime}$ end of the IGS region, therefore showing less homology with the pBG35 probe than the $1.2,1.5$ and $1.7 \mathrm{~kb}$ SacI rDNA fragments from the coding region. The variable rDNA bands detected with EcoRI (Fig. 2a) and Bam HI have not been mapped, except for the rDNA variants BamHI:B and EcoRI:C, which result from a deletion in some of the rDNA repeats present in the genome (see 'Restriction mapping of the parental trees'). 


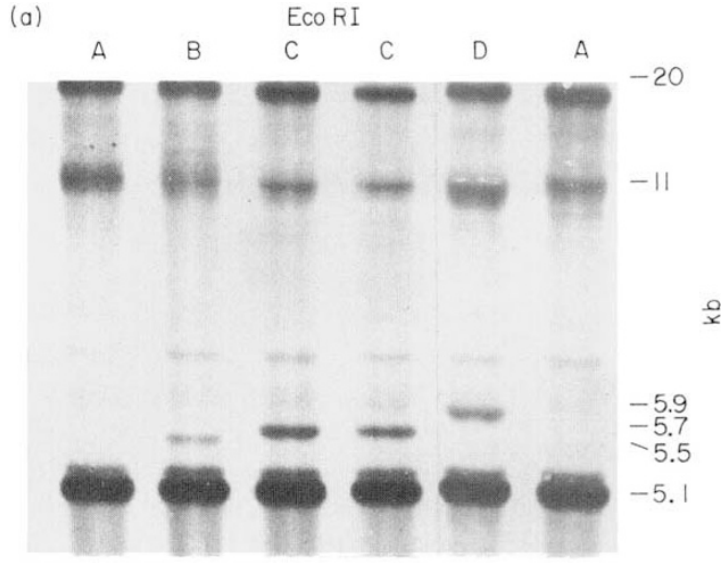

(b) Sac I

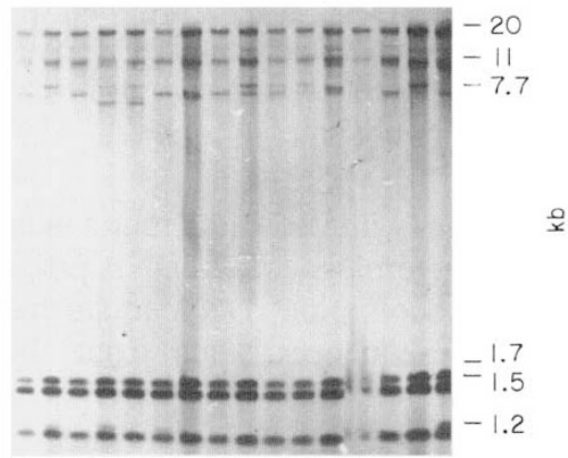

Fig. 2 Examples of variable rDNA hybridization patterns of Scots pine individuals, detected with (a) Eco RI and (b) $S a c I$. Southern blots were hybridized with digoxigenin-labelled flax rDNA repeat (pBG35). The rDNA phenotypes (EcoRI: A-D and $S a c I$ : A-E) and fragment sizes (in kb) can be crossindexed to Table 1.
Fragment-size patterns (rDNA phenotypes) are summarized in Table 1 for BamHI, EcoRI and SacI and designated by letter symbols (A, B, C, etc.). Because the rDNA repeats are organized into at least eight NORs in the haploid Scots pine genome (Karvonen et al., 1993), each rDNA phenotype in Table 1 represents the combined rDNA genotype for all NOR loci. A particular rDNA hybridization pattern, e.g. SacI:D with 8.1 and $7.7 \mathrm{~kb}$ rDNA fragments from the 25S-IGS region, is therefore likely to include rDNA fragments from several (two) types of rDNA repeat present within an individual tree.

\section{Distribution of the rDNA patterns in Scots pine populations}

The distribution of the rDNA variability among Scots pine populations in northern and southern Finland is presented in Table 2. Although as many as 13 variable rDNA patterns were recognized in the present study, many of them had very limited distributions and six of the rDNA patterns were found in only a single individual. The most frequent rDNA phenotype was present in 54 per cent of the individuals. Shannon's information measure, $H$ (Hutcheson, 1970) was used to quantify the amount of rDNA diversity and to apportion this variability into between and within population components (Table 3 ). The average rDNA diversity of the populations was 1.29 , which represents 86 per cent of the total species diversity $\left(H_{\text {pop }} / H_{\text {species }}\right.$, Table 3$)$. Differences between populations account for 14 per cent of the total diversity. Therefore, most of the rDNA

Table 1 Fragment sizes for variable rDNA hybridization patterns

\begin{tabular}{|c|c|c|c|c|c|c|c|c|c|c|c|c|c|c|c|c|c|c|c|c|}
\hline \multicolumn{5}{|l|}{ Bam $\mathrm{HI}$} & \multicolumn{5}{|l|}{ Eco RI } & \multicolumn{11}{|l|}{ SacI } \\
\hline \multirow{2}{*}{$\begin{array}{l}\text { Size } \\
\text { (kb) }\end{array}$} & \multicolumn{4}{|c|}{ Pattern } & \multirow{2}{*}{$\begin{array}{l}\text { Size } \\
(\mathrm{kb})\end{array}$} & \multicolumn{4}{|c|}{ Pattern } & \multirow{2}{*}{$\begin{array}{l}\text { Size } \\
(\mathrm{kb})\end{array}$} & \multicolumn{10}{|c|}{ Pattern } \\
\hline & A & B & $\mathrm{C}$ & $\mathrm{D}$ & & A & B & $\mathrm{C}$ & $\mathrm{D}$ & & A & B & $\mathrm{C}$ & $\mathrm{D}$ & $E$ & F & $\mathrm{G}$ & $\mathrm{H}$ & I & $\mathbf{J}$ \\
\hline$>20$ & + & + & + & + & $>20$ & + & + & + & + & $>20$ & + & + & + & + & + & + & + & + & + & + \\
\hline 6.8 & & & & + & 11.0 & + & + & + & + & 11.0 & + & + & + & + & + & + & + & + & + & + \\
\hline 6.2 & + & + & + & + & 5.9 & & & & + & 9.1 & & & & & + & & & & & \\
\hline 6.0 & & & + & & 5.7 & & & + & & 8.1 & & + & + & + & + & + & + & & & \\
\hline \multirow[t]{8}{*}{5.8} & & + & & & 5.5 & & + & & & 7.7 & + & & & + & + & + & + & & + & + \\
\hline & & & & & 5.1 & + & + & + & + & 7.5 & & & & & & & & & & + \\
\hline & & & & & 1.0 & + & + & + & + & 7.1 & & & + & & + & & & & + & \\
\hline & & & & & & & & & & $\begin{array}{l}6.3 \\
4.8\end{array}$ & & & & & & + & + & & & \\
\hline & & & & & & & & & & 1.7 & + & + & + & + & + & + & + & + & + & + \\
\hline & & & & & & & & & & 1.5 & + & + & + & + & + & + & + & + & + & + \\
\hline & & & & & & & & & & 1.2 & + & + & + & + & + & + & + & + & + & + \\
\hline & & & & & & & & & & 1.1 & & & & & & & & + & & \\
\hline
\end{tabular}

Plus $(+)$ sign indicates presence of a fragment in the pattern. 
Table 2 Distribution of rDNA patterns among Scots pine populations

\begin{tabular}{|c|c|c|c|c|c|c|}
\hline \multicolumn{3}{|l|}{ Pattern } & \multicolumn{4}{|c|}{ No. in population } \\
\hline Bam HI & Eco RI & Sacl & KAA & YLL & $\mathrm{VII}+\mathrm{HAU} \dagger$ & Total \\
\hline $\mathrm{A}$ & A & A & 13 & 15 & 24 & 52 \\
\hline $\mathrm{A}$ & A & B & & & 4 & 4 \\
\hline A & A & $\mathrm{C}$ & & & 2 & 2 \\
\hline $\mathrm{A}$ & A & $\mathrm{D}$ & 11 & 8 & 4 & 23 \\
\hline $\mathrm{A}$ & $\mathrm{A}$ & $E$ & 1 & & 1 & 2 \\
\hline $\mathrm{A}$ & A & $\mathrm{F}$ & 1 & 3 & 2 & 6 \\
\hline A & A & G & & 1 & & 1 \\
\hline $\mathrm{A}$ & A & I & & 1 & & 1 \\
\hline $\mathrm{A}$ & A & $J$ & 1 & & & 1 \\
\hline B & $\mathrm{C}$ & A & & & 2 & 2 \\
\hline B & $\mathrm{C}$ & $\mathrm{H}$ & & 1 & & 1 \\
\hline $\mathrm{C}$ & D & G & & 1 & & 1 \\
\hline $\mathrm{D}$ & B & A & & & 1 & 1 \\
\hline
\end{tabular}

†Seed orchard populations from southern Finland (see Table 3 for full names).

Table 3 Partitioning of the rDNA variability between and within populations using Shannon's diversity index $\left(\mathrm{H}^{\dagger}\right)$

\begin{tabular}{lll}
\hline Grouping & $\mathrm{N}$ & $\mathrm{H}$ \\
\hline$H_{\text {pop }}:$ & & \\
Kaamanen (KAA) & 27 & 1.08 \\
Ylläs (YLL) & 30 & 1.38 \\
$\quad$ Viitaselkä + Hausjärvi (VII + & 40 & 1.40 \\
$\quad$ HAU) & & \\
$\quad$ Mean $\left(H_{\text {popp }}\right)$ & 97 & 1.29 \\
$H_{\text {species }}$ & & 0.86 \\
$H_{\text {popp }} / H_{\text {species }}$ & & 0.14 \\
$H_{\text {species }}-H_{\text {pop }} / H_{\text {species }}$ & & \\
\hline
\end{tabular}

$\dagger \mathrm{H}=-\Sigma p_{\mathrm{i}} \ln p_{\mathrm{i}}$, where $p_{\mathrm{i}}$ is the frequency of the rDNA pattern.

variability in Scots pine results from differences among individuals of a population (including within-individual variability).

\section{Chromosomal distribution of an rDNA variant}

Restriction mapping of the parental trees. During the present study, controlled crosses were available between restricted numbers of the Scots pine clones present in the Hausjärvi seed orchard. From these the cross E636 $\times$ E702 was chosen because it was possible to map the rDNA repeat types present in the parental trees (variability was found within the transcribed region). It was not possible to map the

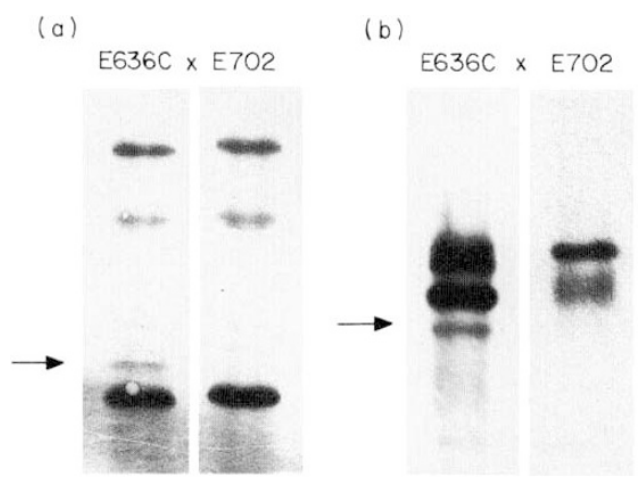

Fig. 3 rDNA hybridization patterns of the parental trees of the cross E636C $\times$ E702, digested with (a) EcoRI and double-digested with (b) XbaI/DraI. rDNA fragment sizes are in kilobases $(\mathrm{kb})$. The $5.7 \mathrm{~kb}$ EcoRI rDNA band and 5.2 $\mathrm{kb} X b a \mathrm{I} / D r a \mathrm{I}$ rDNA band (indicated by arrows) are present only in the maternal parent (E636C) and 16 of 31 individuals of the $F_{1}$ progeny. The Southern blot was hybridized with digoxigenin-labelled pBG35.

rDNA repeats in trees with variability found in the IGS region because the heterologous flax rDNA probe does not hybridize with Scots pine rDNA fragments containing solely IGS sequences. Data from southern hybridizations indicated that the maternal parent E636C contained several types of rDNA repeats (rDNA pattern: Bam HI:B, Eco RI:C, SacI:A), whereas the paternal parent E702 seemed to contain only one type of rDNA repeat and represented the most frequent rDNA genotype in this study (BamHI:A, EcoRI:A, SacI:A; for a restriction map of the rDNA repeat see Karvonen et al., 1993). In the rDNA hybridization patterns of the E636C digested with BamHI, EcoRI, XbaI +DraI, KpnI + DraI, $X b a \mathrm{I}+E c o \mathrm{RV}$ and $K p n \mathrm{I}+E c o \mathrm{RV}$, one additional rDNA fragment was present compared with the rDNA hybridization patterns of the paternal parent E702. However, the extra rDNA fragment of E636C had a hybridization signal of lower intensity than the other rDNA fragments, suggesting that it was present only in a minority of the rDNA repeats. An example of the rDNA hybridization patterns of the $\mathrm{E} 636 \mathrm{C}$ and the E702, digested with EcoRI and $\mathrm{XbaI}+\mathrm{DraI}$, is presented in Fig. 3. Compared with the rDNA patterns of the E702, E636C shows additional rDNA bands both in the EcoRI digestion (5.7 kb rDNA fragment) and $X b a \mathrm{I}+$ DraI double digestion (5.2 kb rDNA fragment).

A restriction map of the rDNA variant producing the extra rDNA fragments in hybridization patterns of the $\mathrm{E} 636 \mathrm{C}$ was constructed using the previous restriction map of the most frequent Scots pine rDNA repeat (Karvonen et al., 1993) as a reference. Table 4 shows the regular size difference of $0.4 \mathrm{~kb}$ between the variant rDNA repeat of E636C and the most frequent rDNA 
Table 4 Informative $\mathrm{CDNA}$ fragment sizes $(\mathrm{kb})$ from the 18S-25S rDNA region of the trees E636C and E702 showing that two types of rDNA repeats exist in the tree E636C: a repeat type similar to the repeats present in the tree E702 and a repeat type carrying a $0.4 \mathrm{~kb}$ deletion in the ITS1 region (compare with the restriction map in Fig. 4)

\begin{tabular}{lll}
\hline \multirow{2}{*}{$\begin{array}{l}\text { Restriction } \\
\text { enzymes }\end{array}$} & \multicolumn{2}{l}{ Tree } \\
\cline { 2 - 2 } & E702 & E636C \\
\hline XbaI+DraI & 5.6 & $5.6,5.2$ \\
XbaI + Eco RV & 3.1 & $3.1,2.7$ \\
KpnI + DraI & 5.6 & $5.6,5.3$ \\
KpnI + Eco RV & 3.2 & $3.2,2.8$ \\
Bam $\mathrm{HI}$ & 6.2 & $6.2,5.8$ \\
EcoRI & $1.0,5.1$ & $1.0,5.1,5.7 \dagger$ \\
\hline
\end{tabular}

†The $5.7 \mathrm{~kb}$ rDNA fragment indicates a deletion of the Eco RI site in the ITS1 region. rDNA fragment size difference between the two repeat types is therefore $(1.0+5.1) \mathrm{kb}-5.7 \mathrm{~kb}=0.4 \mathrm{~kb}$, as in the other digestions in this table.

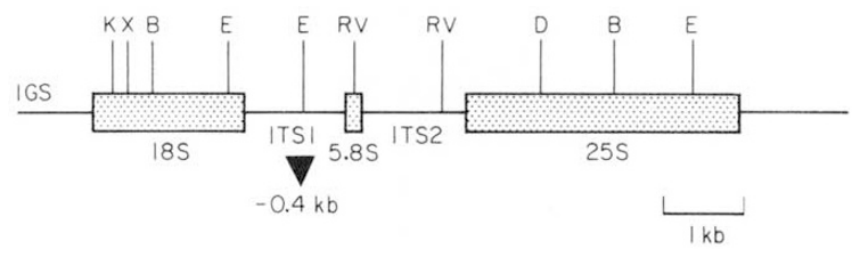

Fig. 4 Schematic restriction map of the Scots pine rDNA repeat showing the site of a $0.4 \mathrm{~kb}$ deletion in the ITS 1 region. The deletion-carrying rDNA variants form a minority of the rDNA repeats in the Scots pine individual E636C (maternal parent in the inheritance study). Only the restriction sites relevant to the present study are shown.

repeat of Scots pine encountered in this study (the 'standard repeat type', present in the paternal parent E702). Based on the restriction data, the EcoRI site of the variant rDNA repeat was deleted from the ITS1 region between the $18 \mathrm{~S}$ and $5.8 \mathrm{~S}$ genes. A schematic restriction map of the rDNA variant carrying a deletion of about $0.4 \mathrm{~kb}$ is presented in Fig. 4. Note that the rDNA repeats carrying a $0.4 \mathrm{~kb}$ deletion formed only a minority of the rDNA repeats in the E636C. The majority of the rDNA repeats in the E636C were similar to the 'standard repeat type'.

Segregation analysis. rDNA hybridization patterns of $31 \mathrm{~F}_{1}$ individuals from the cross $\mathrm{E} 636 \mathrm{C} \times \mathrm{E} 702$ were produced with restriction enzymes $B a m \mathrm{HI}, E c o$ RI and $X b a \mathrm{I}+$ DraI. Sixteen $\mathrm{F}_{1}$ individuals exhibited the female parental rDNA pattern and $15 F_{1}$ individuals the male parental rDNA pattern with all the enzymes used (example in Fig. 3), indicating a situation where one rDNA locus of the mother is heterozygous for the presence of the deletion-carrying rDNA repeats. No structural rearrangements were observed in the rDNA patterns between the progeny and the parents.

The regular segregation pattern of $1: 1$ suggests that the rDNA repeats with a $0.4 \mathrm{~kb}$ deletion are present only at one rDNA repeat array in the maternal parent ('allele' at one NOR locus) and that they segregate in a Mendelian way. However, it is not possible to conclude from these data whether the deletion repeats are the only repeat type present in this particular rDNA array or whether they intermingle with other repeat types.

\section{Discussion}

\section{rDNA variability within Scots pine individuals}

The results in the present study illustrate that there is considerable variation in the Scots pine rDNA although only the transcribed regions and a limited proportion of the intergenic spacer were surveyed. On the basis of rDNA hybridization patterns digested with $B a m \mathrm{HI}, E c o$ RI and SacI, 13 rDNA phenotypes were recognized in a sample of 97 individuals from northern and southern Finland. Each rDNA phenotype represents a combined genotype of the approximately 10000 rDNA repeats present in a diploid Scots pine cell (Ingle et al., 1975), which are organized at a minimum of eight NOR loci (Karvonen et al., 1993).

Variability was found in the IGS and transcribed spacer region of Scots pine rDNA repeats: a situation commonly observed in other plants (Appels \& Dvorak, 1982; Schaal \& Learn, 1988). An individual Scots pine tree seemed to contain several types of rDNA repeats, as indicated by SacI digestions, where one to four rDNA fragments covering the $5^{\prime}$ end of the IGS region could be detected in an individual tree (Fig. 2b). Intraindividual rDNA variation has previously been reported in many plant species, both in angiosperms and conifers. Vicia faba individuals may contain up to 20 different rDNA variants (Rogers et al., 1986) and the mean number of rDNA repeat variants per plant was 1.98 in Phlox divaricata (Schaal et al., 1987), 2.65 in Clematis fremontii (Learn \& Schaal, 1987) and 2.28 in Hordeum vulgare (Saghai-Maroof et al., 1984). In Picea rubens (red spruce) and Picea mariana (black spruce) as many as five rDNA repeat types could be distinguished within individuals (Bobola et al., 1992a, b).

In contrast to the spacer regions, the rRNA coding regions were homogeneous with respect to both length 
and restriction sites within, as well as among, Scots pine individuals. Selective forces are acting to conserve the functionally important secondary structures in rRNA genes and the molecular turnover mechanisms associated with concerted evolution seem to be effective in homogenizing the coding regions, despite large numbers of rDNA repeats and NOR loci is Scots pine. The proposed molecular mechanisms for maintaining homogeneity include biased and non-biased gene conversion, unequal crossing-over and transposition, which can operate within and between chromosomes (Tartof, 1975; Dover, 1982; Ohta \& Dover, 1983, 1984). These mechanisms will either eliminate a new variant (the most frequent event in the absence of biased gene conversion) or increase its frequency until it is tested by natural selection, as suggested by Flavell et al. (1986).

\section{Chromosomal distribution of an rDNA variant}

The inheritance and chromosomal distribution of rDNA variability between NOR loci within a Scots pine individual was studied using as a marker an rDNA repeat carrying a $0.4 \mathrm{~kb}$ deletion in the transcribed spacer. The deletion-carrying rDNA repeats were present only in the maternal parent. The regular inheritance pattern of $1: 1$ in the progeny (31 individuals) led us to conclude that the deletion-carrying rDNA repeats were present only in one rDNA array of the mother tree (in a heterozygous state). Thus, this variant is present only on one chromosome. The deletion-carrying repeats showed regular Mendelian inheritance and no new rDNA patterns were observed in the progeny.

Previously the inheritance and genetic organization of rDNA variants have been studied in only a few plant species, including Hordeum (Saghai-Maroof et al., 1984), Pisum sativum (Ellis et al., 1984; Polans et al., 1986) and Triticum (Snape et al., 1985). In each case the rDNA variants were inherited in a regular Mendelian fashion and were distributed non-randomly among rDNA arrays with respect to chromosomal location. The non-random distribution of rDNA variants across loci has been regarded as evidence that the rate of intrachromosomal exchange (homogenization within an rDNA array) is substantially greater than the rate of interchromosomal exchange (Polans et al., 1986). In humans, the marked linkage disequilibrium of rDNA variants within individuals led Seperack et al. (1988) to suggest that sister chromatid exchanges are much more important than homologous or non-homologous recombination events in the concerted evolution of the rDNA family. Therefore, frequent molecular interactions within chromosomes are able to create the observed within-individual linkage disequilibrium, homogenizing each rDNA array independently of others arrays located on other (homologous or nonhomologous) chromosomes. However, the occurrence of some polymorphic rDNA variants at more than one locus has been observed in primates (Arnheim et al., 1980; Krystal et al., 1981) and Drosophila melanogaster (Coen \& Dover, 1983). Dover (1989) has suggested that chromosome-specific mutations can be considered as relatively recent events which have only had time to be homogenized within an rDNA array and/or between homologous chromosomes. Consequently, a mutation shared around the karyotype would be older and would have existed long enough to have been transferred by rarer non-homologous chromosome exchanges.

\section{rDNA variability in Scots pine populations}

This survey, where only a small number of restriction enzymes was used, can only be used for drawing general conclusions. In this kind of study, nucleotide sampling is a more important source of sampling variance than population sampling, even when 20 restriction enzymes are used (Lynch \& Crease, 1990). Many of the observed rDNA phenotypes of Scots pine had very limited distributions, and nearly half of them were found in only a single individual. Most of the rDNA variability (86 per cent) was found within Scots pine populations (including within-individual variability), whereas differences between populations accounted only for 14 per cent of the total diversity. Although geographical differentiation of rDNA variability has been documented in several plant species, including Clematis fremontii (Learn \& Schaal, 1987), Phlox divaricata (Schaal et al., 1987), Hordeum spontaneum (Chalmers et al., 1992) and Picea rubens and Picea mariana (Bobola et al., 1992a), we found no evidence of significant geographical differentiation in Scots pine rDNA. This is not surprising, as the species showing geographical differentiation are mostly herbaceous perennials or annuals that have very different population structures from pines. Scots pine is characterized by broad range, large, predominantly outcrossing populations and potential for extensive gene flow (Muona, 1989). In contrast, species with clear local differentiation of rDNA variability are characterized by limited gene flow, small population size or geographical isolation that contribute to genetic differentiation among populations. For example, Clematis fremontii occur on small, island-like glades in Missouri, and the local genetic differentiation of rDNA variability is influenced by limited pollen and seed dispersal, as well as genetic drift (Learn \& Schaal, 1987). Also 
Phlox divaricata populations, although widely spread, are geographically isolated and show clear differentiation of rDNA variability among populations (Schaal et al., 1987).

The patterns of rDNA variability in the Scots pine populations agree well with the previous studies where isozymes have been used as genetic markers. Finnish Scots pine populations have high levels of genetic diversity both in natural stands and seed orchards, the average expected heterozygosities at enzyme loci ranging from 0.243 to 0.286 (Muona \& Harju, 1989). No latitudinal differentiation in isozyme allele frequencies has been observed in Northern Europe, as the $G_{\text {ST }}$ values are less than 0.02 (Gullberg et al., 1985; Szmidt \& Muona, 1985). In contrast, quantitative genetic traits related to climatic constraints, e.g. date of bud set, are highly differentiated between Scots pine populations (Eriksson et al., 1980; Mikola, 1982; Muona, 1989), suggesting that geographically differentiated DNA markers are yet to be found.

\section{Acknowledgements}

We thank Dr Chris Cullis for a gift of plasmid pBG35, Dr Peter M. Tigerstedt for guidance at the Hausjärvi seed orchard and Dr Auli Mäkinen for guidance at the Kaamanen standard forest. We also wish to thank Matti Karjalainen, Sirpa Filppula, Gavin Moran, Juanita Morton and all other participitants in the needle collection trips. This work was supported by the National Research Council for Agriculture and Forestry and Foundation for Research on Natural Resources.

\section{References}

APPELS, R. AND DVORAK, J. 1982. The wheat ribosomal DNA spacer region: its structure and variation in populations and among species. Theor. Appl. Genet., 63, 337-348.

ARNHEIM, N., KRYSTAL, M., SCHMICKEL, R., WILSON, G., RYDER, O. AND ZIMMER, E. 1980. Molecular evidence for genetic exchanges among ribosomal genes on non-homologous chromosomes in man and apes. Proc. Natl. Acad. Aci. USA, 77, 7323-7327.

BOBOLA, M. S., ECKERT, R. AND KLEIN, A. S. 1992a. Restriction fragment variation in the nuclear ribosomal DNA repeat unit within and between Picea rubens and Picea mariana. Can. J. For. Res., 22, 255-263.

BOBOLA, M. S., SMITH, D. E. AND KLEIN, A. S. 1992b. Five major nuclear ribosomal repeats represent a large and variable fraction of the genomic DNA of Picea rubens and $P$. mariana. Mol. Biol. Evol., 9, 125-137.

CAPOSSELA, A., SILANDER, J. A. Jr., JANSEN, R. K., BERGEN, B. AND TALBOT, D. R. 1992. Nuclear ribosomal DNA variation among ramets and genets of white clover. Evolution, 46, $1240-1247$.
CHALMERS, K. J., WAUGH, R., WATTERS, J., FORSTER, B. P., NEVO, E., ABBotT, R. J. AND POWELL, w. 1992. Grain isozyme and ribosomal DNA variability in Hordeum spontaneum populations from Israel. Theor. Appl. Genet., 84, 313-322.

ClEGG, M. T. 1989. Molecular diversity in plant populations. In: Brown, A. H. D., Clegg, M. T., Kahler, A. L. and Weir, B. S. (eds), Plant Population Genetics, Breeding and Genetic Resources, Sinauer Assoc., Sunderland, Massachusetts, pp. 98-115.

COEN, E. S. AND DOVER, G. 1983. Unequal exchanges and the coevolution of $\mathrm{X}$ and $\mathrm{Y}$ rDNA arrays in Drosophila melanogaster. Nature, 295, 564-568.

CUllis, C. A., CREISSEN, G. P., GORMAN, S. W. AND TEASDALE, R. D. 1988. The 25S, $18 \mathrm{~S}$ and $5 \mathrm{~S}$ ribosomal RNA genes from Pinus radiata D. Don. In: Cheliak, W. M. and Yapa, A. C. (eds), Molecular Genetics of Forest Trees, Petawawa National Forestry Institute Report, Canada, pp. 34-40.

DOVER, G. 1982. Molecular drive: a cohesive mode of species evolution. Nature, 299, 111-116.

DOVER, G. 1989. Linkage disequilibrium and molecular drive in the rDNA gene family. Genetics, 122, 249-252.

ECKENRODE, V. K., ARNOLD, J. AND MEAGHER, R. B. 1985. Comparison of the nucleotide sequence of soybean $18 \mathrm{~S}$ rRNA with the sequences of other small-subunit rRNAs. J. Mol. Evol., 21, 259-269.

ELlis, T. H. N., DAVIES, D. R., CASTLETON, J. A. AND BEDFORD, I. D. 1984. The organizaton and genetics of rDNA length variants in peas. Chromosoma, 91, 74-81.

ERIKSSON, G., ANDERSSON, S., EICHE, V., IFVER, J. AND PERSSON, A. 1980. Severity index and transfer effects on survival and volume production of Pinus sylvestris in northern Sweden. Stud. For. Suecica, 156, 1-32.

FLAVELL, R. B. AND O'DELL, M. 1990. Variation and inheritance of cytosine methylation patterns in wheat at the high molecular weight glutenin and ribosomal RNA gene loci. Development (Suppl.), 1990, 15-20.

FLAVELL, R. B., O'DELL, M., SHARP, P., NEVO, E. AND BEILES, A. 1986. Variation in intergenic spacer of ribosomal DNA of wild wheat, Triticum dicoccoides in Israel. Mol. Biol. Evol., 3, 547-558.

GoldsBRough, P. B. AND CULLIS, C. A. 1981. Characterization of the gene for ribosomal RNA in flax. Nucleic Acids Res., 9, 1301-1309.

GULLBERG, U., YAZDANI, R., RUDIN, D. AND RYMAN, N. 1985. Allozyme variation in Scots pine (Pinus sylvestris L.) in Sweden. Silv. Genet., 34, 193-201.

HUTCHESON, K. 1970. A test for comparing diversities based on the Shannon formula. J. Theor. Biol., 29, 151-154.

INGLE, J., TIMMIS, J. N. AND SINCLAIR, J. 1975. The relationship between satellite DNA, rDNA gene redundancy, and genome size in plants. Plant Physiol., 55, 496-501.

KARVONEN, P., KARJALAINEN, M. AND SAVOLAINEN, O. 1993. Ribosomal RNA genes in Scots pine (Pinus sylvestris L.): chromosomal organization and structure. Genetica, 88, 59-68.

KING, L. M. AND SCHAAL, B. A. 1989. Ribosomal DNA variation and distribution in Rudbeckia missouriensis. Evolution, 43, 1117-1119. 
KRYSTAL, M., D'EUSTACHIO, P., RUDDLE, F. H. AND ARNHEIM, N. 1981. Human nucleolus organizers on nonhomologous chromosomes can share the same ribosomal gene variants. Proc. Natl. Acad. Sci. USA, 78, 5744-5748.

LEARN, G. H. AND SCHAAL, B. A. 1987. Population subdivision for ribosomal DNA repeat variants in Clematis fremontii. Evolution, 41, 433-438.

LONG, E. O. AND DAWID, I. B. 1990. Repeated genes in eukaryotes. Ann. Rev. Biochem., 49, 727-764

LYNCH, M. AND CREASE, T. J. 1990. The analysis of population survey data on DNA sequence variation. Mol. Biol. Evol., 7, 377-394.

MCMULLEN, M. P., HUNTER, B., PHILLIPS, R. L. AND RUBINSTEIN, I. 1986. The structure of the maize ribosomal DNA spacer region. Nucleic Acids Res., 14, 4953-4968.

MIKol_A, J. 1982. Bud-set phenology as an indicator of climatic adaptation of Scots pine in Finland. Silv. Fenn. 16, $178-184$

MUONA, o. 1990. Population genetics in forest tree improvement. In: Brown, A. H. D., Clegg, M. T., Kahler, A. L. and Weir, B. S. (eds), Plant Population Genetics, Breeding and Genetic Resources, Sinauer Associates Inc., Sunderland, Massachusetts, pp. 282-298.

MUONA, O. AND HARJU, A. 1989. Effective population sizes, genetic variability and mating system in natural stands and seed orchards of Pinus sylvestris. Silv. Genet., 38, $221-228$.

MURRAY, M. G. AND THOMPSON, W. F. 1980. Rapid isolation of high molecular weight plant DNA. Nucleic Acids Res., 8 , 4321-4325.

OHTA, T. AND DOVER, G. A. 1983. Population genetics of multigene families that are dispersed into two or more chromosomes. Proc. Natl. Acad. Sci. USA, 80, 4079-4083.

OHTA, T. AND DOVER, G. A. 1984. The cohesive population genetics of molecular drive. Genetics, 108, 501-521.

POLANS, N. O., WEEDEN, N. F. AND THOMPSON, W. F. 1986. Distribution, inheritance and linkage relationship of ribosomal DNA spacer length variants in pea. Theor. Appl. Genet., 72, 289-295.

ROGERS, S. O. AND BENDICH, A. J. 1987. Ribosomal RNA genes in plants: variability in copy number and in the intergenic spacer. Plant. Mol. Biol., 9, 509-520.

ROGERS, S. O., HONDA, S. AND BENDICH, A. J. 1986. Variation in the ribosomal RNA genes among individuals of Vicia faba. Plant. Mol. Biol., 6, 339-345.
SAGHAI-MAROOF, M. A., SUliman, K. M., JORGENSEN, R. A. AND ALLARD, R. W. 1984. Ribosomal DNA spacer-length polymorphisms in barley: Mendelian inheritance, chromosomal location and population dynamics. Proc. Natl. Acad. Sci. USA, 81, 8014-8018.

SCHAAL, B. A. AND LEARN, G. H. Jr. 1988. Ribosomal DNA variation within and among plant populations. Ann. Missouri Bot. Gard., 75, 1207-1216.

SCHAAL, B. A., LEVERICH, W. J. AND NIETO-SOTELO, J. 1987. Ribosomal DNA variation in the native plant Phlox divaricata. Mol. Biol. Evol., 4, 611-621.

SEPERACK, P., SLATKIN, M. AND ARNHEIM, N. 1988. Linkage disequilibrium in human ribosomal genes: implications for multigene family evolution. Genetics, 119, 943-949.

SNAPE, J. W., FLAVELL, R. B., O'DELL, M., HUGHES, W. G. AND PAYNE, P. I. 1985. Intrachromosomal mapping of the nucleolar organizer region relative to three marker loci on the chromosome $1 \mathrm{~B}$ of wheat (Triticum aestivum). Theor. Appl. Genet., 69, 263-270.

SZMIDT, A, E. AND MUONA, O. 1985. Genetic effects of Scots pine (Pinus sylvestris L.) domestication. In: Gregorius, H. R. (ed.), Population Genetics in Forestry; Lecture Notes in Biomathematics 60, Springer-Verlag, Berlin, pp. 241-252.

tartoF, K. D. 1975. Redundant genes. Ann. Rev. Genet., 9. 355-385.

TRemousaygue, D., GRellet, F., Delseny, M., Delourme, R. AND RENARD, M. 1988. The large spacer of a nuclear ribosomal RNA gene from radish: organization and use as a probe in rapeseed breeding. Theor. Appl. Genet. 75, 298-304.

VENKATESWARLU, K. AND NAZAR, R. 1991. A conserved core structure in the 18-25S rRNA intergenic region from tobacco, Nicotiana rustica. Plant Mol. Biol., 17, 189-194.

WAGNER, D. B., FURNIER, G. R., SAGHAI-MAROOF, M. A., WILLIAMS, S. M., DANCIK, B. P. AND ALlARD, R. W. 1987. Chloroplast DNA polymorphism in logdepole and jack pines and their hybrids. Proc. Natl. Acad. Sci. USA, 84, 2097-2100.

WATSON, J. C., KAUFMANN, L. S. AND THOMPSON, W. F. 1987. Developmental regulation of cytosine methylation in the nuclear ribosomal RNA genes of Pisum sativum. J. Mol. Biol., 193, 15-26.

YAKURA, K., KATO, A. AND TANIFUJI, s. 1984. Length heterogeneity of the large spacer of Vicia faba rDNA is due to the differing number of a 325 bp repetitive sequence elements. Mol. Gen. Genet., 193, 400-405. 